\title{
KINETIC REGULARITIES AND MATHEMATICAL MODELLING OF POTASSIUM CHLORIDE DISSOLUTION
}

\author{
Dmytro Symak ${ }^{1}$, Vira Sabadash $^{1}{ }^{凶}$, Jaroslaw Gumnitsky $^{1}$, Zoriana Hnativ $^{1}$
}

https://doi.org/10.23939/chcht15.01.148

\begin{abstract}
The dissolution process of potassium chloride particles in the apparatus with two-blade mechanical stirrer was investigated and the mass transfer coefficient was determined. The experimental results were generalized by criterion dependence. The independence of the mass transfer coefficient from the solid particles diameter was confirmed. A countercurrent process of potassium salt dissolution in two apparatuses with a mechanical stirring was considered. A mathematical model for countercurrent dissolution was developed and the efficiency of this process was determined.
\end{abstract}

Keywords: dissolution, kinetics, mass transfer, mass transfer coefficient, mixing, mathematical model.

\section{Introduction}

Dissolution processes are widely used in chemical, food, hydrometallurgical and environmental technologies. Dissolution is a mass exchange process in a solid-liquid system, due to which the concentration of the dissolved component in the solution increases and the resulting solution is subjected to further processing. In most cases, the dissolution takes place in the diffusion region, the flow rate of which is determined by hydrodynamics. A mass transfer coefficient, which characterizes the dissolution intensity, is determined under experiments. This coefficient depends on the intensity of the solid-liquid system mixing and indicates the possibility of the process intensification. Dissolution is widely used in the halurgy industry during the processing of potassium natural salts [1,2].

The industrial continuous dissolution of potassium ores implies the multi-tonnage production and the simultaneous use of alternate stirring and transporting mechanisms. This creates a continuity of the process. Dissolution occurs in screw dissolvers which do not create conditions for the suspended staying of solids particles in the apparatus. The latter fact significantly reduces the dissolution surface and the mass transfer coefficient due to

\footnotetext{
${ }^{1}$ Lviv Polytechnic National University,

12, S. Bandera St., 79013 Lviv, Ukraine

virasabadash@gmail.com

(C) Symak D., Sabadash V., Gumnitsky J., Hnativ Z., 2021
}

the low relative velocities of fluid and solid phases. In recent publications the dissolution was studied using not only aqueous solutions but also other media which allow to intensify the process. The processes of copper biodegradation from old flotation tails [3], dissolution in ionic liquids [4], drugs dissolution in pure liquids using the focused reflected ray [5] are of urgent attention. Many authors investigated the solubility of solids in different solvents and conditions, in particular, the effect of volume change on the dissolution degree of silica in hydrofluoric acid [6], the solubility of disodium inorine-5 monophosphate in pure and mixed solvents [7], acrylic acid in organic solvents [8], calcium carbonate in ammonium chloride solutions [9], hematite in aqueous solutions at $\mathrm{pH}=1$ [10]. The process thermodynamics was studied on the example of coumarin dissolution in different pure solvents [11].

Many researchers focus on the study of dissolution kinetics and intensification. The equilibrium and kinetic regularities of dissolution are given in [2]. Technological processes, where dissolution is a main stage, including the production of potash fertilizers, are described in [12-14]. Mass transfer in solid phase systems is analyzed in [15], where the experimentally determined mass transfer coefficient is compared with the theoretical value obtained on the basis of theoretical analysis of isotropic turbulence. Mathematical modelling of non-stationary dissolution processes is reporesented in [16], taking into account that the dissolution surface and the concentration of a substance in a liquid change over time. The process of dissolving copper sulfate, located between inert phases, is discussed in [17]. This process combines both the dissolution and the extraction of the dissolved component. An analogy of dissolution and adsorption is given in [18]. Mass transfer during dissolution in mechanical stirring apparatus is examined in [19]. The dissolution and mass transfer processes accompanied by a chemical reaction are considered in $[20,21]$. A significant effect of the gas phase released on the surface of the solid-liquid system on the increase of mass transfer coefficient due to the turbulence of the boundary diffusion layer is shown in [22].

The industrial process of potassium ore dissolution is a multi-tonnage one and the dissolution process is 
characterized by significant volumes. Trough-shaped apparatuses (dissolvers), in which the stirring and transportation of potassium salt with the insoluble solid phase are carried out by means of screw devices, are widely used. In horizontal screw dissolvers the solid phase is transported by a screw conveyor, and the liquid phase flows by gravity. However, the ineffective stirring provides low mass transfer coefficients and long process time resulting in the apparatus of great volumes $[13,14]$. So, the dissolution intensification is of great interest. Among the various methods, dissolution in the gas-liquid stream is noteworthy. During dissolution in the batch or cocurrent reactors, the concentration of the dissolved compound is changed which significantly influences the driving force of the process and changes the dissolution rate.

Many works are devoted to the problems of mass transfer intensification in solid-liquid systems. Among various methods there is an introduction of inert gas phase into the system [23] allowing to achieve a significant increase in the mass transfer coefficient. In some studies, the inert phase is produced by creating a vacuum in the system [24]. The vapor bubbles are formed on the solid surface of the salt and destroy the boundary diffusion layer, which leads to the phenomenon of instability characterized by high kinetic coefficients. The dissolution processes discussed above relate to one solid substance in different solvents and different intensification methods. Basically, they consider dissolving in one laboratory apparatus under certain temperature and hydrodynamic conditions, various solvents and sizes of the solid phase. However, there is a need to investigate the industrial-scale dissolution of the solid phase, including potassium salts used as fertilizers for agriculture.

The purpose of this study was to investigate the dissolution of the potassium salt in the apparatus equipped with a two-blade mechanical stirrer, to determine the stirring efficiency, to summarize the experimental results by the criterion dependence and to present the calculation method for dissolvers in the countercurrent scheme of dissolution.

\section{Experimental}

\subsection{Theoretical Analysis of the Dissolution Process and Modelling of Industrial Apparatus}

According to the theory of heat and mass transfer, the experimental results appear to be generalized variables. In the case of solids dissolution, the hydrodynamics is estimated by the Reynolds number for mixing $\left(\mathrm{Re}_{m}\right)$, the physico-chemical parameters of the system by the Schmidt number $(S c)$, the diffusion-mass transfer characteristics by the Sherwood number $(S h)$. Generalization of the experiments is represented by Eq. (1):

$$
S h=f\left(\operatorname{Re}_{m}, S c\right)
$$

where $S h=\frac{\beta \cdot d}{D} ; \operatorname{Re}_{m}=\frac{\rho \cdot n \cdot d_{m}{ }^{2}}{\mu} ; S c=\frac{\mu}{\rho \cdot D}$

$D$ is the molecular diffusion coefficient of potassium chloride in water, $\mathrm{m}^{2} / \mathrm{s} ; \rho$ is the density of the liquid, $\mathrm{kg} / \mathrm{m}^{3} ; \mu$ is the coefficient of dynamic viscosity of the liquid, $\mathrm{Pa} \cdot \mathrm{s} ; \mathrm{n}$ is the number of revolutions of the stirrer; $d$ is the particle diameter of the solid phase, $\mathrm{m} ; d_{m}$ is the stirrer diameter, $\mathrm{m}$.

Equations for determining the mass-transfer coefficient given in the literature [2] make it possible to represent the coefficient $\beta$ in the criterion form for certain conditions and different types of stirrers. Each of these dependencies determines that the Sherwood number is proportional to the Reynolds number in the first degree. used [2]:

For this purpose, the mass transfer equation was

$$
\Delta M=\beta \cdot F \cdot\left(C_{S}-C\right) \cdot \Delta \tau
$$

Expressing the change in the mass by the liquid volume and the component concentration in the liquid, the value of the mass transfer coefficient was determined according to Eq. (3):

$$
\beta=\frac{W \cdot C_{k}}{F_{s}\left(C_{S}-C\right) \Delta \tau}
$$

where $\Delta M$ is the change in the solid phase mass, $\mathrm{kg} ; F$ is the dissolution surface, $\mathrm{m}^{2} ; C_{s}$ is the saturation concentration, $\mathrm{kg} / \mathrm{m}^{3} ; C$ is the average concentration over a period of time, $\mathrm{kg} / \mathrm{m}^{3} ; C_{k}$ is the final concentration at a given time interval, $\mathrm{kg} / \mathrm{m}^{3} ; W$ is the liquid volume, $\mathrm{m}^{3}$.

\subsection{Experimental Procedure}

We have investigated the dissolution of potassium chloride in an apparatus with a mechanical stirrer, which allows to transfer the solid phase to a suspended state. This updates the dissolution surface and accordingly increases the mass transfer coefficient. The experimental setup is represented in Fig. 1.

Distilled water $\left(W=1.0 \mathrm{dm}^{3}\right)$ with the salt initial concentration $\left(C_{0}=0 \mathrm{~kg} / \mathrm{m}^{3}\right)$ was placed in a cylindrical vessel. A pre-prepared and dispersed potassium chloride fraction was loaded into the apparatus. The average fraction size was $1,2,3$ and $4 \mathrm{~mm}$. These values were used for the calculation of the dissolution process. The weight of the solid phase $M_{0}=300 \mathrm{~g}$, corresponds to a concentration of complete dissolution and is approximately equal to the saturation concentration. 


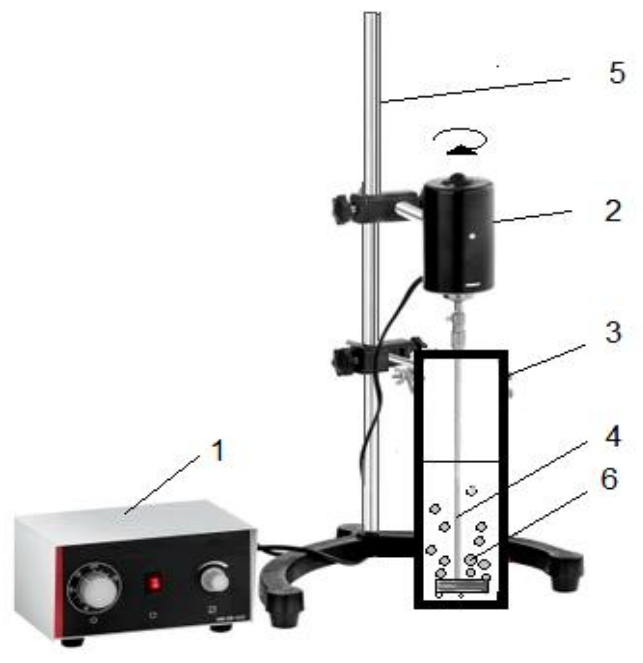

Fig. 1. Experimental setup to study the dissolution kinetics: digital controller of the revolutions number (1); stirrer motor (2); vessel with salt solution (3); blade stirrer (4); support (5); solid phase (6)

The solution was stirred with a blade stirrer 4 $\left(d_{m}=0.05 \mathrm{~m}\right.$ and $\left.h=0.02 \mathrm{~m}\right)$. The stirrer speed was set by a digital speed controller 1 and varied within the limits $n=200-600 \mathrm{rpm}$. The stirrer was rotated by means of motor 2, the number of revolutions was determined by the tachometer. This number of revolutions provided sufficient contact of solid particles with the liquid. The dissolution was carried out at the temperature of $293 \pm 0.5 \mathrm{~K}$.

After setting a predetermined number of revolutions, some salt was loaded and a stopwatch came on. Samples were withdrawn after definite time intervals and analyzed for dissolved salt content. The concentration of chlorine ions was determined via the argentometric method.

\subsection{Dissolution Process for Two Serial Apparatuses}

Each apparatus for the continuous dissolution process (Fig. 2) is a mechanical stirred reactor. The solid and liquid flows move countercurrent, i.e., this scheme corresponds to the flow scheme discussed in [25]. The apparatus to which the fresh solvent is supplied is designated as the first one, and the apparatus to which the solid phase is supplied will be regarded as the second one.

A fresh solvent with a flow rate $W_{C}$ and an initial concentration $C_{0}$ is fed into the first apparatus. The second apparatus is loaded with the initial solid phase with a flow rate $M_{0}$ and the liquid phase from the first apparatus after the separator 3. The solid phase from the second apparatus after the separator 3 is collected in the solid waste collection. The concentrated solution from the separator after the second apparatus is transferred for further processing.

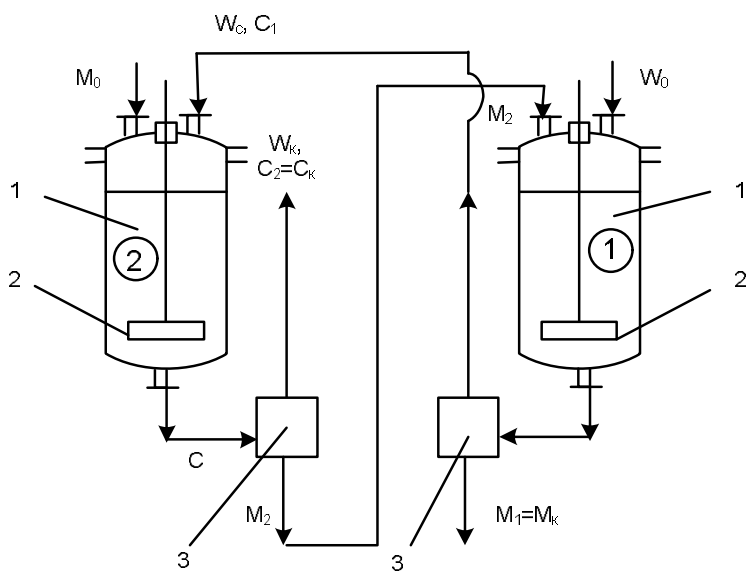

Fig. 2. Scheme of two-section countercurrent dissolution using mechanical stirred reactors: dissolver (1); blade stirrer (2) and separator (3)

\section{Results and Discussion}

The results of experimental studies and theoretical calculations of the mass transfer coefficient were performed according to the methods given in Section 2.

The changes in potassium chloride concentration with time $C=f(\tau)$, which were calculated according to the experimental results, are presented in Fig. 3.

The experimental data were used to determine the mass transfer coefficient.

At the initial stages of dissolution (Fig. 3), the changes in concentration is linear, so these values allowed us to establish the dependence of the mass transfer coefficient on the solid particles diameter, taking the concentration $C$ as an arithmetic mean in Eq. (2). The dependence of the mass transfer coefficient $\beta$ for different numbers of revolutions $n$ and different initial diameters $d_{0}$ is shown in Fig. 4.

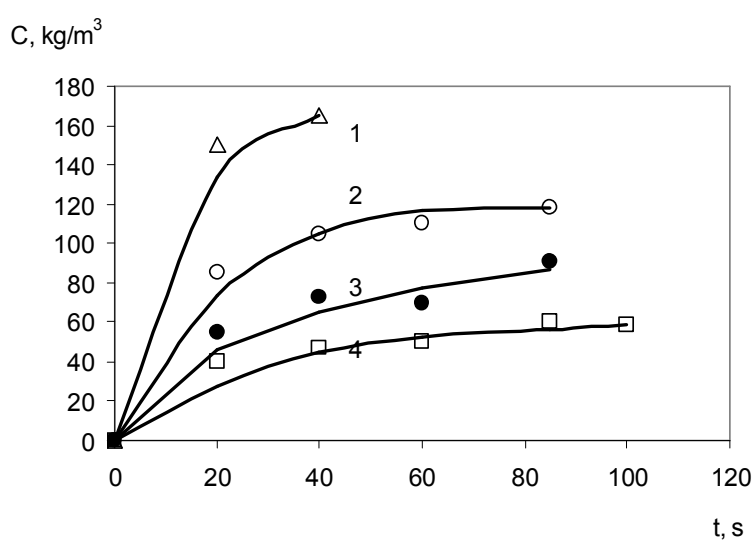

Fig. 3. Potassium chloride concentration in the solution $v s$. dissolution time for the revolutions number of $300 \mathrm{l} / \mathrm{min}$ for different initial diameters $d_{0}, \mathrm{~m}$ :

$2 \cdot 10^{-3}(1) ; 3 \cdot 10^{-3}(2) ; 4 \cdot 10^{-3}(3)$ and $5 \cdot 10^{3}(4)$ 


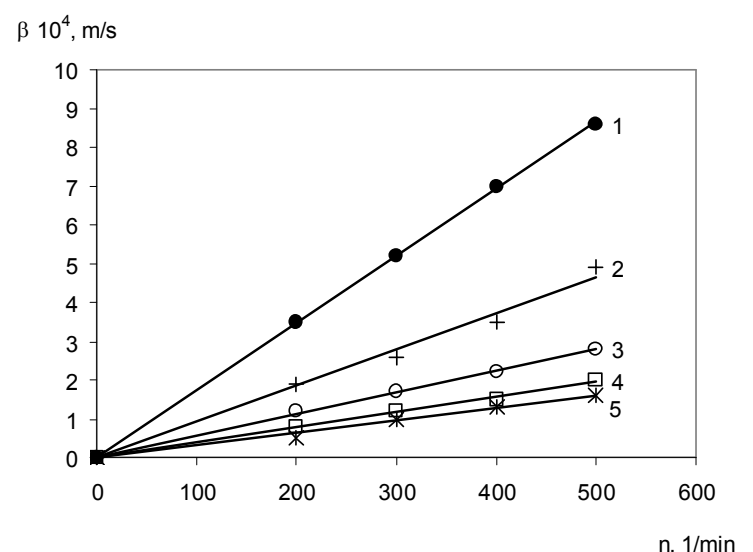

Fig. 4. Mass transfer coefficient $v s$. number of revolutions for different diameters of the solid particles $d, \mathrm{~m}$ : $1 \cdot 10^{-3}(1) ; 2 \cdot 10^{-3}(2) ; 3 \cdot 10^{-3}(3) ; 4 \cdot 10^{-3}(4)$ and $5 \cdot 10^{-3}(5)$

As can be seen from Fig. 4, there is a direct linear dependence of the mass transfer coefficient on the number of revolutions of the stirring device. These data correlate with the dependencies given in the literature for other types of stirrers [2]. Taking into account that during experiments all parameters, except for the number of revolutions, are the same, the mass transfer coefficient is directly proportional to the Reynolds number in the first degree.

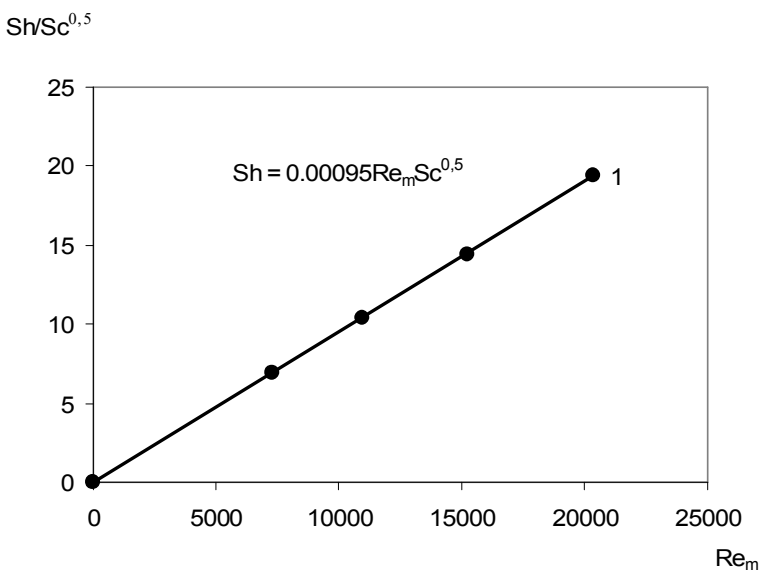

Fig. 5. Generalization of the investigation results of the potassium chloride dissolution in the apparatus with a two-blade stirrer

Given in the literature criterion dependencies for different stirring devices are proportional to the Schmidt number in the degree of $0.5\left(S c^{0.5}\right)$. Taking into consideration the dissolution of only one substance at a constant temperature of $293 \mathrm{~K}$, the Schmidt number has the same value for all experiments, namely $S c=521.6$. Generalized values of experimental studies of potassium chloride dissolution are shown in Fig. 5 as $S h / S c^{0.5}=f\left(\operatorname{Re}_{m}\right)$. Each point on the graph corresponds to the arithmetic mean of 5 studies with an error not exceeding $1 \%$. The criterion equation describing the dissolution in a stirred apparatus has a view:

$$
S h=9.5 \cdot 10^{-4} \operatorname{Re}_{m} \cdot S c^{0.5}
$$

\subsection{Mathematical Model of Potassium Salt Countercurrent Dissolution}

The dissolution studies presented above allowed us to determine the mass transfer coefficients for different numbers of revolutions and sizes of solid phase.

The mass transfer equation (1) and the material balance are the basis for calculating the two-section dissolution process. For the first apparatus, these equations are:

$$
\begin{aligned}
& -\frac{d M}{d \tau}=\beta \cdot F\left(C_{S}-C_{1}\right) \\
& M_{2}-M_{1}=W_{C}\left(C_{1}-C_{0}\right)
\end{aligned}
$$

Expressing the mass and dissolution surface of the solid phase through the diameter $d$, we obtain the differential kinetics equation in which the change in diameter is a function of time:

$$
-\int_{d_{2}}^{d_{1}} d(d)=\frac{2 \beta}{\rho_{S}}\left(C_{S}-C_{1}\right) \int_{\tau_{1}}^{\tau_{2}} d \tau
$$

The solution of Eq. (6) for the first and second apparatuses is:

$$
\begin{aligned}
& d_{2}-d_{1}=\frac{2 \beta}{\rho_{S}}\left(C_{S}-C_{1}\right) \Delta \tau \\
& d_{0}-d_{2}=\frac{2 \beta}{\rho_{S}}\left(C_{S}-C_{2}\right) \Delta \tau
\end{aligned}
$$

where $\rho_{s}$ is the density of the solid phase, $\mathrm{kg} / \mathrm{m}^{3}$.

The material balance for two solvents is:

$$
\begin{aligned}
& M_{0}-M_{2}=W_{C}\left(C_{2}-C_{1}\right) \\
& M_{2}-M_{k}=W_{C}\left(C_{1}-C_{0}\right)
\end{aligned}
$$

Expressing the mass of solids through the diameter $d$ and their number $N$, the material balance for the second and first solvents is:

$$
\begin{aligned}
& N \cdot \rho_{S} \cdot \frac{\pi}{6}\left(d_{0}^{3}-d_{2}^{3}\right)=W_{C}\left(C_{2}-C_{1}\right) \\
& N \cdot \rho_{S} \cdot \frac{\pi}{6}\left(d_{2}^{3}-d_{1}^{3}\right)=W_{C}\left(C_{1}-C_{0}\right)
\end{aligned}
$$

When introducing a dimensionless diameter $\varphi=\frac{d_{i}}{d_{0}}$, Eq. (7) converts into Eq. (10)

$$
\begin{gathered}
\varphi_{2}-\varphi_{1}=A\left(C_{S}-C_{1}\right) \\
1-\varphi_{2}=A\left(C_{S}-C_{2}\right)
\end{gathered}
$$

where the parameter $A=\frac{2 \beta \cdot \Delta \tau}{\rho_{S} \cdot d_{0}}$ is a constant value because, as it was mentioned above, the $\beta$ value does not 
depend on the diameter of the solid phase for stirring at the same temperature and stirring intensity.

The material balance of the system using the dimensionless diameter $\varphi$ is:

$$
\begin{aligned}
& 1-\varphi_{2}^{3}=B\left(C_{2}-C_{1}\right) \\
& \varphi_{2}^{3}-\varphi_{1}^{3}=B\left(C_{1}-C_{0}\right)
\end{aligned}
$$

in which the parameter $B=\frac{6 d_{0}^{3} \cdot W_{C}}{N \cdot \pi \cdot \rho_{S}}$ is also constant.

The concentrations $C_{1}$ and $C_{2}$ determined from Eq. (11), were substituted into Eq. (10):

$$
\begin{aligned}
& \varphi_{2}=1-A \cdot C_{S}+\frac{A}{B}\left(1-\varphi_{1}^{3}\right) \\
& \varphi_{1}=1-2 A \cdot C_{S}+\frac{A}{B}\left(1-2 \varphi_{1}^{3}+\varphi_{2}^{3}\right)
\end{aligned}
$$

We have calculated the countercurrent dissolution process of the solid phase (salt with $M_{0}=4 \mathrm{~kg} / \mathrm{s}$ ) and the solvent $\left(W_{C}=0.02 \mathrm{~m}^{3} / \mathrm{s}\right)$ in two apparatuses. Potassium salt with an average diameter of $4 \mathrm{~mm}$ was dissolved. The mass transfer coefficient was found to be $1.2 \cdot 10^{-4} \mathrm{~m} / \mathrm{s}$. The calculation allowed to establish that for the second dissolver, which is the first relative to the solid phase, the value of the relative diameter at the apparatus outlet is 0.691 , after the first apparatus it is equal to 0.22 . The dissolution efficiency $\eta$ was determined in accordance with Eq. (13):

$$
\eta=\frac{M_{0}-M_{k}}{M_{0}}=1-\varphi_{1}^{3}=0.989
$$

The calculated data [25] on the dissolution in screw dissolvers after 6 cells, each of which is analogous to one stirred dissolver, give an efficiency equal to 0.936 . The comparison of two technological schemes shows that the mass transfer coefficient has the greatest influence on the process and its value for the screw dissolver is lower by an order than for the apparatus with a mechanical stirring.

\section{Conclusions}

An experimentally investigated dissolution of potassium chloride in a mechanical stirring apparatus with a two-blade stirrer made it possible to establish the independence of the mass transfer coefficient from the solid phase diameter. The experimental data are represented by the criterion dependence, allowing to theoretically determine the mass transfer coefficient. A scheme of countercurrent dissolution is proposed and a mathematical model for this process is drawn up.

\section{References}

[1] Zdanovskyi, A.: Galurgia. Khimia, Leningrad 1972.

[2] Akselrud G., Molczanov A.: Rastvoreniye Tviordykh Veshczestv. Khimia, Moskva 1977.

[3] Stankovic S., Moric I., Pavic A.,Vojnovic S. et al.: J. Serb. Chem. Soc., 2015, 80, 391. https://doi.org/10.2298/JSC140411097S
[4] Okuniewski M., Ramjugernath D., Paramespri N., Domanska U.: J. Chem. Thermodyn., 2014, 77, 23.

https://doi.org/10.1016/j.jct.2014.04.021

[5] Tully G., Hou G., Glen B.: Chem. Eng. Data, 2016, 61, 594. https://doi.org/10.1021/acs.jced.5b00746

[6] Shvartsev B., Gelman D., Komissarov I., Epshtein A. et al.: Chem. Phys. Chem., 2015, 16, 370. https://doi.org/10.1002/cphc.201402627

[7] Zou F., Zhuang W., Wu J. et al.: J. Chem. Themodyn., 2014, 77, 14. https://doi.org/10.1016/j.jct.2014.04.023

[8] Yu X., Shen Z., Sun Q. et al.: J. Chem. Eng. Data, 2016, 61, 1236. https://doi.org/10.1021/acs.jced.5b00880

「9] Zhao H., Chen J., Liu C. et al.: J. Chem. Eng. Data, 2015, 60, 3201. https://doi.org/10.1021/acs.jced.5b00417

[10] MacCarthy J., Nosrati A., Skinner W., Addai-Mensah J.: Chem. Eng. Res. Des., 2014, 92, 2509. https://doi.org/10.1016/j.cherd.2014.02.020

[11] Huang X., Wang J., Hao H. et al.: Fluid Phase Equilibria, 2015, 394, 148. https://doi.org/10.1016/j.fluid.2015.03.022

[12] Morgenstern L.: Teor. Osnovy Khim. Tekhn., 2014, 48, 122.

[13] Khacevycz O., Artus M., Kostiv I.: Khim. Prom. Ukrainy, 2015, 3, 37.

[14] Artus M., Kostiv I.: Khim. Prom.Ukrainy, 2015, 6, 39.

[15] Symak D., Atamaniuk V., Gumnitskyy Y.: Chem. Chem. Technol., 2015, 9, 493. https://doi.org/10.23939/chcht09.04.493

[16] Babenko Yu., Ivanov, E.: Teor. Osnovy Khim. Tekhn., 2015, 47, 624.

[17] Gumnitsky J., AtamaniukV., Symak D.: Integr. Technol. ta Energozbererzennia, 2017, 4, 23.

[18] Sabadash V., Mylanyk O., Matsutska O., Gumnytsky J.: Chem. Chem. Technol., 2017, 11, 459. https://doi.org/10.23939/chcht11.04.459 [19] Patil V., Joshi J., Sharma M.: Chem. Eng. Res. Des., 1984, 62, 247. https://doi.org/10.1002/cjce.5450620210

[20] Wang Z., Zhou J., Zhu J. et al.: Huagong xuebao = SIESC J., 2015, 66, 1001 .

[21] Frikha N., Hmercha A., Gabsi S.: Can. J. Chem. Eng., 2014, 92, 1829. https://doi.org/10.1002/cjce. 21986

[22] Viten'ko T., Gumnitskii J.: Theor. Found. Chem. Eng., 2006, 40, 598. https://doi.org/10.1134/S0040579506060078

[23] Gumnitsky J, Symak D., Nagurskyy O.: Naukovi praci ONAChT, $2015,47,130$.

[24] Gumnitsky J., Yurym M., Venger L.: Visnyk NU ”Lvivska Politechnika", 2003, 488, 220.

[25] Symak D., Atamaniuk V., Sklabinskyy V. et al.: Naukovyy Visnyk NLTU, 2018, 28, 117.

Received: February 10, 2019 / Revised: May 23, 2019 / Accepted: August 13, 2019

\section{КІНЕТИЧНІ ЗАКОНОМІРНОСТI ТА МАТЕМАТИЧНЕ МОДЕЛЮВАННЯ РОЗЧИНЕННЯ КАЛІЙ ХЛОРИДУ}

Анотація. Досліджено прочес розчинення частинок калій хлориду в апараті з механічним перемішуванням дволопатевою мішалкою та визначено коефічіснт масовіддачі. Експериментальні результати узагальнено критеріальною залежністю. Підтверджено незалежність коефіцієнта масовіддачі від діаметра твердих частинок. Розглянуто протитечійний прочес розчинення калійної солі у двох апаратах з механічним перемішуванням. Розроблено математичну модель для протитечійного розчинення та визначено ефективність даного процесу.

Ключові слова: розчинення, кінетика, масовіддача, коефіцієнт масовіддачі, перемішування, математична модель. 